\title{
Herbage yield and quality relationships of three varieties of Setaria sphacelata (Schumach.) Stapf and Hubbard
}

\author{
A. J. P. van Wijk \\ National Agricultural Research Station, Kitale, Kenya
}

Accepted: 17 January 1976

Key words: herbage, quality, Setaria sphacelata, yield, tropical grasses

\section{Summary}

Primary growth of three varieties of Setaria sphacelata (Schumach.) Stapf \& Hubbard was cut at 3-week intervals during 1973 and 1974. Dry matter yield, \% digestible organic matter and \% crude protein of the dry matter and some morphological characters were determined at each cut. When compared at a given date digestibility of the three varieties did not differ significantly, but at the same growth stage the early heading variety was higher in digestibility than the late heading varieties. The early variety had a significantly higher dry matter production (total of five cuts) than the late varieties when the two years were combined.

During initial stages of growth, stem digestibility was higher than leaf digestibility, for which leaf sheaths can be held responsible. Therefore the higher stem percentage of the early variety as compared to the late varieties did not affect overall digestibility adversely at that stage. It is concluded that by increasing the leaf percentage at mature stages of growth together with the selection of early heading plants, both dry matter yield and quality can be improved without prejudice to seed production.

\section{Introduction}

From temperate grasses it is known that the beginning of ear emergence is the point at which the fall of digestibility changes from a slow to a high rate (Minson et al., 1960). This decline is associated with changes in the percentage and digestibility of leaf blade, leaf sheath and stem (Terry \& Tilley, 1964). A late heading variety extends its vegetative growth to flowering time over a longer period than early varieties, leaving more time for the farmer to utilize nutritious herbage.

It is generally believed that tropical grasses are very stemmy and therefore the selection of late heading varieties was thought to be even more justified. In line with this thinking Bogdan (1965) developed in Setaria sphacelata (Schumach.) Stapf \& Hubbard the late heading variety Nandi II out of Nandi I. Out of Nandi II a later heading variety, named Nandi III, was selected with a high leaf to stem ratio and a good growth vigour (Dougall, 1967). However, in terms of seed production, already 
low in cultivated tropical grasses, Nandi II and Nandi III proved to be inferior to Nandi I, while yield of dry matter of Nandi III was lower than that of Nandi I (Boonman \& van Wijk, 1973).

The object of this study was to investigate the relationship of herbage yield, quality and some morphological characteristics of the three varieties. If more insight into these relationships can be obtained, breeding objectives may be properly defined to improve both characters without sacrificing seed production.

As yield and quality are exposed to continuous alterations during the growing season, it is of paramount importance to establish criteria for comparison. In temperate grasses numerous comparative studies on yield and quality relationships have been conducted. At a given date variation in digestibility in vitro could be attributed largely to differences in growth stages (Walters et al., 1967). Early heading varieties were more digestible than late heading varieties at the same growth stage (Dent \& Aldrich, 1963). Green et al., (1971) studied yield and quality of various grasses in their development up to flowering by cutting primary growth at 10 -day intervals. Varieties can then be compared at any given yield of dry matter or level of digestibility independent of growth stage. The latter method was applied in the present experiment of the three Setaria varieties.

\section{Materials and methods}

On 20 June 1972 the varieties Nandi I, Nandi II and Nandi III were planted in a randomized block design with three replicates, each block measuring $92 \mathrm{~m}^{2}$. The grasses were sown by hand, at a rate of $1 \mathrm{~kg}$ pure germinating seed per ha in rows $25 \mathrm{~cm}$ apart. Single super phosphate was applied at $40 \mathrm{~kg} \mathrm{P}_{2} \mathrm{O}_{5}$ per ha at time of planting. Hand weeding was carried out during the first two weeks of August. On 19 August 1972 all blocks received $40 \mathrm{~kg} \mathrm{~N}$ per ha as ammonium sulphate nitrate. No observations were taken and the grass was cut back on 29 December 1972. After a cleaning cut on 25 April 1973, the experiment was fertilized with ammonium sulphate nitrate at a rate of $40 \mathrm{~kg} \mathrm{~N}$ per ha.

Each block was divided into 10 plots of $1.50 \times 6.00 \mathrm{~m}$. Five adjacent plots of primary growth were cut at $3,6,9,12$ and 15 weeks after the cleaning cut. The remaining five plots were left undisturbed for harvesting in the following year.

At harvest time $50 \mathrm{~cm}$ was discarded from both ends of each plot, while along the plot two rows were used as a guard row on the side of the previous cut. The grasses were cut at $10 \mathrm{~cm}$ above ground level.

In each plot tillers were counted in situ in sections of $25 \mathrm{~cm}$ row length at four random places. A sample of tillers was obtained by cutting a line diagonally across the plot. 100 tillers were taken at random from the sample and number of heading and non-heading tillers were determined as defined by Boonman (1971).

The whole plot was cut by hand with sickles and the weight of the fresh material was determined. A sample of $500 \mathrm{~g}$ of the harvested grass was oven dried at $100{ }^{\circ} \mathrm{C}$ and weighed.

A second sample of $500 \mathrm{~g}$ of fresh material was taken and separated into leaf blades, stems (including leaf sheaths) and dead material. The components were 
Table 1. Dry matter yield $\left(\mathrm{kg} / 10 \mathrm{~m}^{2}\right)$ in 1973 and 1974 (averages of 3 replicates).

\begin{tabular}{lcccc}
\hline Year & $\begin{array}{l}\text { Weeks after the } \\
\text { cleaning cut }\end{array}$ & Nandi I & Nandi II & Nandi III \\
1973 & 3 & 1.7 & & \\
& 6 & 4.8 & 1.2 & 1.5 \\
& 9 & 15.6 & 4.3 & 4.0 \\
& 12 & 8.3 & 8.4 \\
& 15 & & 9.8 & 9.9 \\
1974 & & 11.9 & 12.7 \\
& 3 & 4.7 & 2.3 & 2.2 \\
& 6 & 6.9 & 3.9 & 4.5 \\
& 9 & 10.7 & 6.6 & 5.5 \\
& 12 & 10.1 & 8.5 & 10.2 \\
\hline
\end{tabular}

oven dried and weighed. The dried whole plant samples and the leaf and stem samples were ground and analysed for $\%$ digestible organic matter of the dry matter (D value) according to Tilley \& Terry (1963). The Kjeldahl method was used to determine the nitrogen content of the dry matter of the whole plant samples.

In 1974 a cleaning cut was carried out on 21 March after which the experiment was fertilized with $40 \mathrm{~kg} \mathrm{~N}$ per ha. The five plots that were not sampled the previous year were harvested at $3,6,9,12$ and 15 weeks respectively after the cleaning cut. The fresh weight of the plot and the dry weight of a $500 \mathrm{~g}$ fresh sample were recorded. The $\mathrm{D}$ value and the nitrogen content were determined as described above.

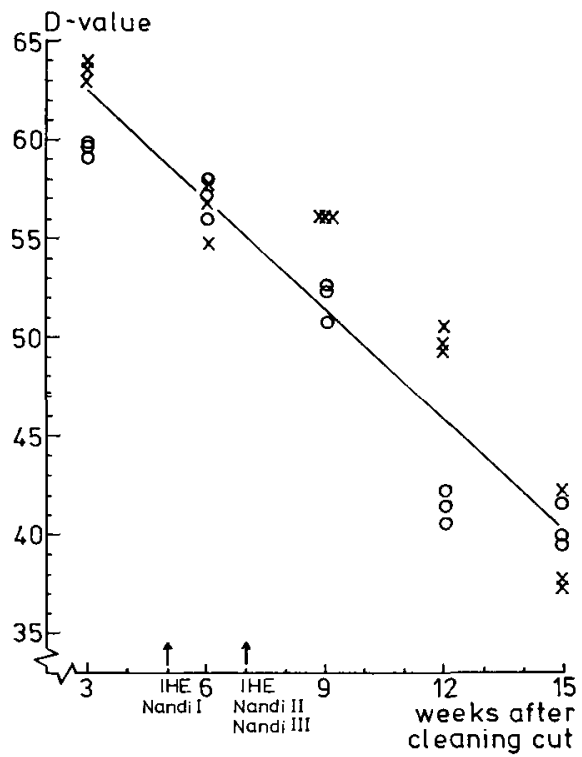

Fig. 1. Effect of age on the D value of Nandi I, Nandi II and Nandi III in 1973 and 1974. Y = $-1.85 \mathrm{X}+68.07\left(\mathrm{r}_{28}=-0.94\right)$.

$\mathrm{o}=1973$ values; $\mathrm{x}=1974$ values. 


\section{Results}

The dry matter yields at various stages of growth are presented in Table 1. In 9 out of the 10 cuts Nandi I yielded more than Nandi II and Nandi III. Differences in total yield between varieties were only significant in $1973(\mathrm{P}<0.05)$. A combined analysis of variance of the 2 years for total dry matter yields revealed that Nandi I was significantly different from Nandi II and Nandi III $(P<0.01)$. A significant year effect $(P<0.01)$ existed and the year $\times$ variety interaction was not significant $(P>0.05)$. At about 12 weeks after the cleaning cut dry matter yield levelled off or even declined, which was accompanied by a decreasing tiller number per $\mathrm{m}^{2}$.

During the growing season the $\mathrm{D}$ value dropped at a linear rate against time $(\mathrm{P}<0.01)$ as shown in Fig. 1. Differences in digestibility between varieties were small and not significant in 1973 and $1974(P>0.05)$. Differences between the two years were significant $(\mathrm{P}<0.01)$ and the year $\times$ variety interaction was not significant $(P>0.05)$. The drop in digestibility per day for the three varieties in 1973 and 1974, expressed as \% digestibility units was 0.26 as calculated from Fig. 1. The significance of the variety effect, the year effect and the year $\times$ variety interaction for crude protein content (nitrogen content $\times 6.25$ ) was the same as for the $\mathrm{D}$ value. Crude protein content $(\mathrm{Y})$ dropped at a linear rate with time (X) $(P<0.01)$ for the three varieties in 1973 and 1974: $\mathrm{Y}=-1.05 \mathrm{X}+18.12\left(\mathrm{r}_{28}=\right.$ -0.81 ).

A significant linear relationship existed between dry matter yield and $D$ value $(P<0.01)$ for the three varieties in 1973 and 1974 (Fig. 2). The differences between

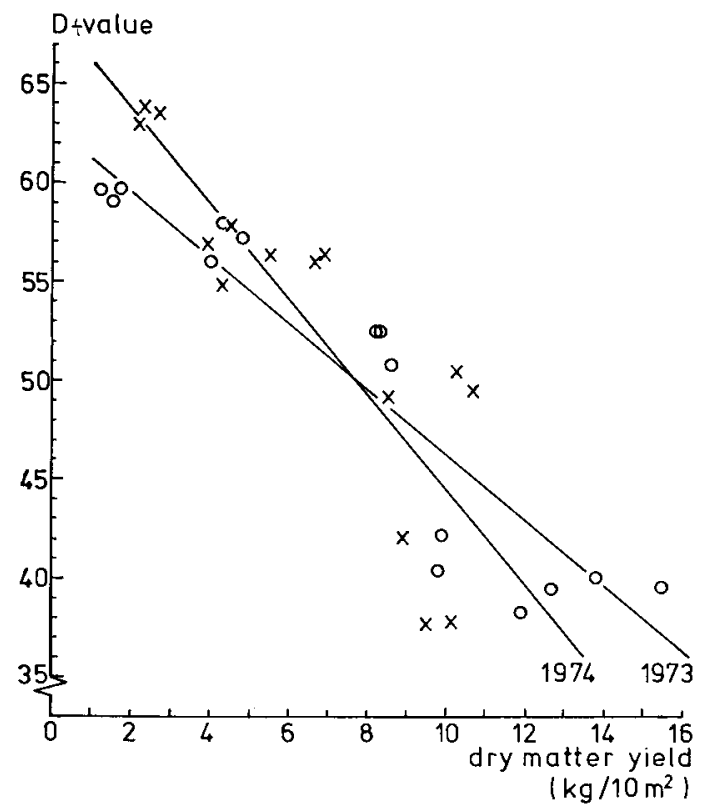

Fig. 2. The relationship between dry matter yield $\left(\mathrm{kg} / 10 \mathrm{~m}^{2}\right)$ and $\mathrm{D}$ value of Nandi I, Nandi II and Nandi III in 1973 and 1974. 1973: $\mathrm{Y}=-1.67 \mathrm{X}+62.86$ $\left(r_{13}=-0.93\right) ; 1974: Y=-2.40 X+$ $68.47\left(\mathrm{r}_{13}=-0.85\right)$.

$\mathrm{o}=1973$ values; $\mathrm{x}=1974$ values. 
Table 2. The D values of leaves and stems at different ages in 1973 (averages of 3 replicates).

\begin{tabular}{lcccc}
\hline & $\begin{array}{l}\text { Weeks after the } \\
\text { cleaning cut }\end{array}$ & Nandi I & Nandi II & Nandi III \\
Leaves & 3 & 58.6 & 59.2 & 56.2 \\
& 6 & 57.8 & 58.7 & 58.8 \\
& 9 & 56.2 & 55.3 & 55.7 \\
& 12 & 49.0 & 50.5 & 49.5 \\
Stems & 49.8 & 50.4 & 51.3 \\
& & & & \\
& 3 & 60.6 & 60.2 & 57.3 \\
& 6 & 56.8 & 57.4 & 55.3 \\
& 9 & 50.8 & 51.1 & 40.1 \\
\hline
\end{tabular}

the 1973 and 1974 values could not be accounted for. However, the slope and the elevation of the two regression lines did not differ significantly $(P>0.05)$.

Changes in digestibility of leaves and stems during the various stages of growth are shown in Table 2. From the data presented it is clear that the digestibility of the stems declined at a much faster rate than that of the leaves. In the early stages of growth (three weeks after the cleaning cut) stem digestibility was 1-2 percentage units higher than that of the leaves. At 15 weeks after the cleaning cut stem digestibility lagged 14 digestibility units behind leaf digestibility.

From the number of tillers per $\mathrm{m}^{2}$ and the percentage of heading tillers the number of heading tillers per $\mathrm{m}^{2}$ was calculated. When 10 heads per $\mathrm{m}^{2}$ had emerged, the variety had reached its initial stage of head emergence (IHE) (Boonman, 1971). When based on weekly intervals Nandi I reached IHE five weeks after the cleaning cut, while Nandi II and Nandi III followed 2 weeks later.

In Fig. 3 the percentage of stems is plotted against time. Stem percentage of Nandi I was consistently higher than that of Nandi II and Nandi III when compared at a given time. At time of IHE stem percentages of Nandi II and Nandi III were higher than that of Nandi I.

No marked differences between varieties for the amount of dead material occurred (data not presented here). In the last cut of 1973 dead material amounted to $14 \%$ of the dried $500 \mathrm{~g}$ sample.

\section{Discussion}

The sole aim of the grazier is to produce leafy pastures and to retain them in that condition throughout the growing season. The breeding of late heading varieties, seen as ideal by Davies (1960), would contribute to the achievement of this goal. For many years it was accepted that these varieties were of higher quality than early varieties because of their deferred flowering. Early varieties had good yields in both herbage and seed but their going into stem rapidly was considered as a sign of their poor quality. 


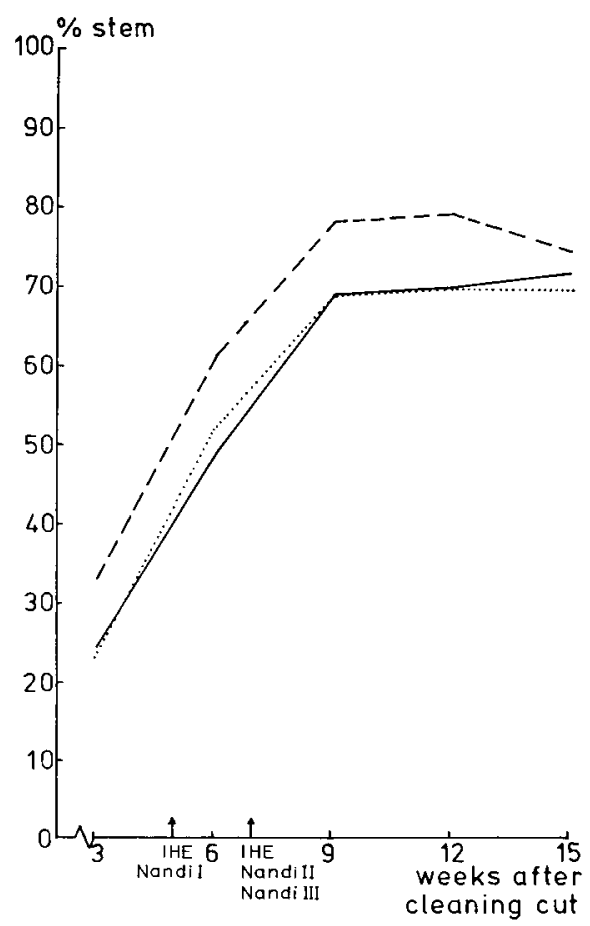

Fig. 3. Effect of age on stem percentage of Nandi I, Nandi II and Nandi III in 1973 (averages of 3 replicates).

——— Nandi I; — Nandi II;

In 1963, Dent \& Aldrich demonstrated the higher quality of early varieties when compared with late varieties at the same growth stage. Late varieties reach a certain morphological stage at a later point of time than early varieties because of their slower growth rate. Sullivan (1965) reported that slow growing tissue was more lignified than tissue of fast growing plants, resulting in a lower digestibility. The ageing of the leaves and the higher temperatures in temperate areas at which late varieties attain the same growth stage of early varieties might explain the poorer quality (Deinum \& Dirven, 1971). Walters et al. (1967) attributed the lower digestibility at a given growth stage to the relative higher proportion of dead material in the late varieties.

At time of IHE Nandi I displayed a higher digestibility (58.8) than Nandi II and Nandi III (55.1) as calculated from Fig. 1. The slower growth rate of the late varieties could account for this difference as temperatures were constant during the time of observations and no marked differences existed between varieties for the amount of dead material accumulated. The lower digestibility of Nandi II and Nandi III might have been caused by their higher stem percentages compared to Nandi I at time of IHE (Fig. 3).

The crude protein content fell rapidly as the grass matured. It took about 10 weeks after the cleaning cut before the crude protein content fell below $7 \%$. Milford \& Minson (1966) suggested that bacterial activity in the rumen of the 
grazing animal is depressed by lack of nitrogen at that level. The $\mathrm{D}$ value was approximately $50 \%$ at that time.

Raymond (1963) stated: 'If one genotype is of higher yield than another when both are at the same level of digestibility, then the first genotype is likely to be of higher digestibility when both are harvested at the same yield'. When extended to a varietal base the early variety is expected to have a higher digestibility than the late variety when compared at a given level of dry matter yield. This is because the early variety reaches this yield level at an earlier point of time than the late variety and the early variety will have a higher digestibility as is clear from Fig. 1. However no significant differences for D value between Nandi I, Nandi II and Nandi III could be detected at the same yield level. Apparently the contrast between the growth rate of the three varieties was not big enough. If an earlier variety than Nandi I could be bred a correlated response in $\mathrm{D}$ value might be expected.

The daily drop in digestibility of leaves was 0.11 (expressed as \% digestibility units) as compared to 0.29 for stems, calculated from the regression of time on leaf and stem digestibility for the three varieties in 1973. At three weeks growth the digestibility of the stem fraction, solely consisting of leaf sheaths that surround young unexpanded leaf tissue, was higher than leaf digestibility, whereafter the digestibility of the stems dropped at a much faster rate than the digestibility of the leaves. In young material of Dactylis glomerata leaf sheaths had a higher in vitro digestibility than leaf blades (Terry \& Tilley, 1964). In vitro digestibility of leaf sheaths and leaf blades were approximately equal in Lolium perenne and Festuca arundinacea in young stages of growth (Deinum \& Dirven, 1975). The data presented here indicate that the leaf sheaths might be held responsible for the higher digestibility of the stem fraction in young stages of growth.

The proportion of stems of Nandi I was during the first 3 cuts almost 10 percentage units higher than Nandi II and Nandi III, but as the grasses matured differences became smaller (Fig. 3). In the initial stages of growth the higher stem percentage of Nandi I did not affect the whole plant digestibility adversely because of its high digestibility. In more advanced stages when stems had a significantly lower digestibility than leaves the higher stem percentage of Nandi I acted negatively on the whole plant digestibility. A high leaf percentage in the advanced stages of growth will therefore improve whole plant digestibility. Whole plant digestibility can be calculated from the organic matter weights of leaves and stems and their respective digestibilities. The regression between the observed (Y) and the calculated (X) data of 1973 was $Y=1.00 X-0.02\left(r_{13}=0.99\right)$.

Using the average digestibilities of leaves and stems of the three varieties at 6,9 , 12 and 15 weeks after the cleaning cut as presented in Table 2 and assuming different leaf and stem proportions, the expected whole plant digestibility was calculated. Increasing the proportion of leaves by $10 \%$ units means that digestibility is improved with $0.1,0.5,0.8$ and $1.3 \%$ digestibility units at $6,9,12$ and 15 weeks, respectively.

Selecting plants with a high leaf proportion is meaningful when the plants are compared at the same growth stage. Screening for leafiness at a given date in tropical grasses will only result in a late heading variety, as was the case with Nandi III. 
Variation for leaf number was observed in a spaced plant population of Nandi I at the time of IHE (van Wijk, unpublished data), late heading plants tending to have more leaves. Boonman \& van Wijk (1973) found that early heading plants were more vigorous and had a higher head number than late heading plants. Improvement for both herbage yield and quality can be made by selecting early heading plants (growth vigour) with many leaves (quality) if such plants occur. By selecting early plants seed production will be increased simultaneously.

\section{Acknowledgments}

This paper is published with the permission of the Director of Agriculture, Kenya. The author wishes to thank Mr P. K. Njoroge, from the National Agricultural Research Station, Kitale for the in vitro digestibility analyses and the nitrogen content determinations.

\section{References}

Bogdan, A. V., 1965. Cultivated varieties of tropical and sub-tropical herbage plants in Kenya. E. Afr. agric. For. J. 30: 330-338.

Boonman, J. G., 1971. Experimental studies on seed production of tropical grasses in Kenya. 2. Tillering and heading in seed crops of eight grasses. Neth. J. agric. Sci. 19: 237-249.

Boonman, J. G. \& A. J. P. van Wijk, 1973. Experimental studies on seed production of tropical grasses in Kenya. 7. The breeding for improved seed and herbage productivity. Neth. J. agric. Sci. 21: 12-23.

Davies, W., 1960. The grass crop. Spon, London.

Deinum, B. \& J. G. P. Dirven, 1971. Climate, nitrogen and grass. 4. The influence of age on chemical composition and in vitro digestibility of maize (Zea mays L.) and tall fescue (Festuca arundinacea Schreb.). Neth. J. agric. Sci. 19: 264-272.

Deinum, B. \& J. G. P. Dirven, 1975. Climate, nitrogen and grass. 6. Comparison of yield and chemical composition of some temperate and tropical grass species grown at different temperatures. Neth. J. agric. Sci. 23: 69-82.

Dent, J. W. \& D. T. A. Aldrich, 1963. The inter-relationship between heading date, yield, chemical composition and digestibility in varieties of perennial ryegrass, timothy, cocksfoot and meadow fescue. J. nat. Inst. agric. Bot. 9: 261-281.

Dougall, H. W., 1967. A. Rep. Dept. Agric., Kenya 1964: 95-112.

Green, J. O., A. J. Corral \& R. A. Terry, 1971. Relationships between stage of growth, yield and forage quality. Tech. Rep. Grassld Res. Inst. No 8.

Minson, D. J., W. F. Raymond \& C. E. Harris, 1960. Studies in digestibility of herbage. VIII. The digestibility of S 37 cocksfoot, S 23 ryegrass and S 24 ryegrass. J. Brit. Grassld Soc. 15 : 174-180.

Raymond, W. F., 1969. The nutritive value of forage crops. Adv. Agron. 21: 1-108.

Sullivan, J. T., 1969. Chemical composition of forages with reference to the needs of the grazing animal. U.S. Dept. Agric. ARS 54-107.

Terry, R. A. \& J. M. A. Tilley, 1964. The digestibility of the leaves and stems of perennial ryegrass, cocksfoot, timothy, tall fescue, lucerne and sainfoin, as measured by an in vitro procedure. J. Br. Grassld Soc. 19: 363-372.

Tilley, J. M. A. \& R. A. Terry, 1963. A two-stage technique for the in vitro digestion of forage crops. J. Br. Grassld Soc. 18: 104-111.

Walters, R. J. K., G. ap Griffith, R. Hughes \& D. I. H. Jones, 1967. Some factors causing differences in digestibility of grasses measured by an in vitro method. J. Br. Grassld Soc. 22: $112-116$. 